\title{
Heat Transfer through Vertically Downward Blowing Single-Jet Air Curtains for Cold Rooms
}

\author{
MARNIX VAN BELLEGHEM \\ Department of Flow, Heat and Combustion Mechanics, Ghent University, Ghent, Belgium \\ GREGORY VERHAEGHE \\ Department of Flow, Heat and Combustion Mechanics, Ghent University, Ghent, Belgium \\ CHRISTOPHE T'JOEN \\ Department of Flow, Heat and Combustion Mechanics, Ghent University, Ghent, Belgium \\ Department Radiation, Radionuclides \& Reactors, Delft University of Technology, Delft, The \\ Netherlands \\ HENK HUISSEUNE \\ Department of Flow, Heat and Combustion Mechanics, Ghent University, Ghent, Belgium \\ PETER DE JAEGER \\ Department of Flow, Heat and Combustion Mechanics, Ghent University, Ghent, Belgium \\ NV Bekaert SA, Zwevegem, Belgium \\ MICHEL DE PAEPE \\ Department of Flow, Heat and Combustion Mechanics, Ghent University, Ghent, Belgium
}

One of the major sources of heat gain in refrigerated storage rooms is the infiltration of warm ambient air through doorways. Air curtains reduce this amount of heat transfer by blowing a plane air jet in the doorway while allowing an easy passage of the traffic. An air curtain device installed at the doorway of a cold room in a supermarket was studied in detail. Thermographic images were taken, recording the temperature field across the doorway. Tracer gas decay measurements were used to estimate the air flow rate through the door. These measurements were then used to validate a Computational Fluid Dynamics (CFD) model of the air curtain. With this CFD model the impact of some important air curtain parameters, such as the jet velocity and the jet nozzle width, on the heat transfer rate through the opening is determined. Finally, an expression to estimate the heat transfer rate through the air curtain is proposed.

Address correspondence to Michel De Paepe, Department of Flow, Heat and Combustion Mechanics, Ghent University, Sint-Pietersnieuwstraat 41, 9000 Ghent, Belgium

E-mail: Michel.depaepe @ugent.be

Tel. : +3292643294

Fax. : +32 92643576 


\section{INTRODUCTION}

Refrigerated storage rooms (cold rooms) account for a large portion of the energy use in different sectors (department stores, grocery stores, distribution warehouses...). Because of increasing environmental awareness and rising energy prices, there is a strong drive to improve the insulation of these storage rooms and to reduce the heat gains.

One of the major sources of heat gain in refrigerated storage rooms is the infiltration of warm ambient air through doorways. In the 2010 ASHRAE handbook - Refrigeration [1] it is stated that infiltration loads can amount to more than half the total refrigeration load. Air infiltration can also be a source of ice or mist forming. Because these storage rooms are frequently accessed by for example customers in department stores, easy access is necessary, without leaving the doorway open. Therefore an effective sealing that still allows an easy passage could reduce the energy use significantly.

Commonly used methods for reducing infiltration are PVC strip curtains and fast-sliding doors. Sometimes a vestibule or air lock is used, often in combination with these strip curtains or fastsliding doors. Another possible solution, which allows an easier passage of traffic, is the use of an air curtain.

Air curtains are commonly used to shield stores from infiltrating cold outside air. For example air curtains are installed at the entrance of stores who leave their door open (for commercial reasons). The air curtain creates an aerodynamic sealing while the doorway is still open and free for passage. The customer is less withheld to enter the store and immediately feels the warm air jet when entering the store. Nowadays this technology is also being used for cold storage rooms (to prevent warm air from getting in).

An air curtain or ACD (air curtain device) consists of one or several fans that blow a planar jet of air across the doorway. The jet prevents the free air movement through the doorway, caused by natural convection. The air curtain is thus able to reduce the amount of mass and heat transported through the doorway. Besides cold stores, air curtains are also used for heating applications, such as heated buildings and furnaces, or to prevent the circulation of smoke, dust and odours.

There is a wide variety of commercially available air curtain devices. They are used to shield large doorways for vehicles, at doorways for human traffic (stores) and for display cabinets. Vertically downwards blowing air curtains are the most common, especially in the case of cold 
stores, but also upwards blowing and horizontal jets are used [2]. Some ACD's are provided with a system for the recirculation of the blown air, but mostly the air is simply drawn from the indoor or outdoor surroundings. There may be some provision for the heating or even cooling of the air to increase comfort. Some air curtains consist of two or three parallel jets. This is very often the case when used to restrict infiltration into refrigerated display cabinets [3]. This paper will mainly focus its study on vertical single jet air curtains used to reduce infiltration loads in cold stores.

As already mentioned, the cooling load of a cold room is to a great extent determined by the infiltration load. An optimal air curtain design would result in a minimal infiltration load through the air curtain and thus reduce the energy use for refrigeration. This paper provides the means to estimate the heat transfer rate through a vertical air curtain taking into account various parameters such as outlet velocity, nozzle width and door geometry. This allows for an optimization of the air curtain design.

In this paper first an experimental test case is described. The measurement results from this case were used to validate a CFD (computational fluid dynamics) model of a vertical downward blowing air curtain. Past studies [4-7] showed that CFD can be a useful tool for heat transfer assessment in buildings and building applications. This CFD model was then used to perform a parameter study from which the correlation between various parameters (outlet velocity, nozzle width, door geometry) and the heat transfer can be determined.

\section{Characteristics of an air curtain}

Hayes and Stoecker [8,9] also considered the case of a vertically downwards blowing air curtain without recirculation, mounted at the doorway of an airtight room. They assumed a 2D jet. The air jet is affected by the pressure difference $\Delta p$ across the doorway. For an airtight room, this pressure difference mainly consists out of two contributions. The first is a result of the operation

of the air curtain itself. Air is taken from one space but is blown into both spaces, which causes a pressure build-up. This pressure, which is called the auxiliary pressure $\Delta \mathrm{p}_{\mathrm{a}}$, causes a deflection of the jet directed towards the space from which the air is taken. The second component of $\Delta \mathrm{p}$ is due to the temperature difference $\Delta \mathrm{T}$ across the door which causes a density difference. It is called the stack pressure $\Delta \mathrm{p}_{\mathrm{s}}$ and varies linearly from the top to the bottom of the opening. Using expressions for $\Delta \mathrm{p}_{\mathrm{a}}$ and $\Delta \mathrm{p}_{\mathrm{s}}$, Hayes and Stoecker [8,9] were able to integrate momentum 
equations for a control volume at the jet centreline, which provides analytical equations to determine the shape of the air jet. To counter the deflection of the air jet and to increase the stability of the jet, the outlet of the air curtain is often positioned at an angle relative to the vertical axis (here indicated by $\alpha_{0}$ ). Experimental [8,9] and numerical [2] results showed that an air curtain has the highest stability for an angle $\alpha_{0}$ from $15^{\circ}$ to $20^{\circ}$ (directed to the warm side). This way the deflection caused by the stack effect, directed to the cold side, is countered. A schematic representation of an air curtain is shown on Figure 1 together with geometric definitions.

The stability of the air jet is determined by two effects. The destabilizing factor is the stack pressure caused by the temperature difference. A higher temperature difference tends to deflect the jet. The stabilizing factor is the outlet momentum of the jet. The dimensionless parameter that assesses the stability of the jet, is the deflection modulus $D_{m}$. The deflection modulus is the ratio of the outlet momentum of the jet (the stabilizing factor) to the temperature difference (the destabilizing factor). Some authors use the Richardson number to assess the stability of an air curtain $[10,11]$ (Eq. (2)). This number is the ratio of gravitational forces to the momentum forces. It indicates the relative importance of natural to forced convection and is similar to the inverse of the deflection modulus.

$$
\begin{aligned}
& D_{m}=\frac{\rho_{0} b_{0} v_{0}^{2}}{g H^{2}\left(\rho_{c}-\rho_{w}\right)}=\frac{b_{0} v_{0}^{2} T_{c} T_{w}}{g H^{2} T_{0}\left(T_{w}-T_{c}\right)} \\
& R i=\frac{G r}{\operatorname{Re}^{2}}=\frac{g \beta H\left(T_{w}-T_{c}\right)}{v_{0}^{2}}
\end{aligned}
$$

In the equation of the deflection modulus $\mathrm{D}_{\mathrm{m}}(1), \rho_{0}$ represents the density of air at the jet nozzle exit $\left[\mathrm{kg} / \mathrm{m}^{3}\right], \rho_{\mathrm{c}}$ the air density in the cold room $\left[\mathrm{kg} / \mathrm{m}^{3}\right], \rho_{\mathrm{w}}$ the air density in the warm room $\left[\mathrm{kg} / \mathrm{m}^{3}\right], \mathrm{b}_{0}$ is the width of the jet nozzle $[\mathrm{m}], \mathrm{g}$ is the gravitational acceleration $\left[\mathrm{m} / \mathrm{s}^{2}\right], \mathrm{v}_{0}$ the velocity of the air at the jet nozzle $[\mathrm{m} / \mathrm{s}]$ and $\mathrm{H}$ is the door height $[\mathrm{m}]$. In Eq. (2) $\beta$ is the thermal expansion coefficient $\left[\mathrm{K}^{-1}\right], \mathrm{Gr}$ is the Grashof number (based on the height and the temperature difference between the sides) and Re the Reynolds number (based on the air velocity at the nozzle exit and the nozzle width). 
When the temperature difference across the air curtain is too large, resulting in a too large pressure difference across the curtain, the air jet can completely deflect and will never reach the ground. This is called breakthrough [8]. In this case the air curtain looses its ability to shield the cold environment. Sometimes the breakthrough jet even causes larger air and heat transfer across the doorway, than would be the case when no air curtain is present.

Hayes and Stoecker [8] provide an expression for the minimal theoretical outlet momentum needed to ensure that the air jet reaches the opposite side of the opening and to avoid so-called breakthrough of the air curtain. The sign of Eq. (4) depends on the use of interior or exterior air (+ for exterior, - for interior), relative to the shielded environment.

$$
\begin{aligned}
D_{m, \text { min }} & =\frac{-\sin \alpha_{f}-\sin \alpha_{0}+2-2 \sqrt{\left(1-\sin \alpha_{f}\right)\left(1-\sin \alpha_{0}\right)}}{2\left(\sin \alpha_{f}-\sin \alpha_{0}\right)^{2}} \\
\sin \alpha_{f} & = \pm 2.4 \sqrt{\frac{b_{0}}{H}}\left(1-2.56 \frac{b_{0}}{H}\right)
\end{aligned}
$$

In Eqs. (3) and (4) $\alpha_{0}$ represents the jet inlet angle of the air curtain and $\alpha_{\mathrm{f}}$ is the jet impingement angle as also shown in Figure 1. In reality the momentum of the air jet should be higher since the minimum momentum corresponds with the stability border. Therefore a safety factor between 1.3 and 2 is suggested for the outlet velocity [12].

When the assumption of an airtight room is not valid, the pressure difference $\Delta p$ across the doorway has to be extended with some extra correction terms, as proposed by Sirén [13,14]. When an air curtain is used at an outdoor opening, an extra term is needed to account for the influence of the wind. Another correction has to be made for any imbalance in ventilation flows. This imbalance can have several causes. Firstly, the mechanical ventilation, used to provide the room with fresh air, could be poorly balanced. Another possibility is the extraction of smoke or dust in industrial buildings. The most important reason however is the leakage of air by natural convection. All these factors increase the instability of an air curtain and stress the need for a well estimated safety factor. 
A factor that was not taken into account in this study was the temperature of the jet itself. Some air curtain devises are equipped with a heating or cooling installations (depending on the application) allowing an air jet temperature different from the environment temperatures. Since the air curtains studied in this paper were not equipped with such a cooling or heating device, possible influence of the jet temperature on the air curtain performance was not investigated.

Most studies on air curtains were performed numerically or analytically assuming 2D-flow and neglecting the effect of a finite door width. Foster et al. [15] however showed that 3D effects can have a severe impact on the air curtain effectiveness and suggested therefore to use at least an air curtain over the entire width of the door.

\section{Performance evaluation of an air curtain}

A series of experiments were performed on a test case where an air curtain was installed in the doorway of a cold store. Details of the case study and the measurement results are discussed further on. First, to evaluate the performance of an air curtain, it is useful to introduce a property that indicates how well a doorway is shielded. Therefore, to express how effective an air curtain is in reducing the heat transfer through a doorway, the ASHRAE [1] suggests the use of an effectiveness $\eta$, defined as follows:

$$
\eta=1-\frac{q}{q_{\text {open }}}
$$

Here $\mathrm{q}[\mathrm{W}]$ is the heat flow through the doorway when a shielding device is present and $\mathrm{q}_{\text {open }}$ [W] is the heat transfer when no device is present. In other words, an open door would have an effectiveness $\eta=0$, a perfectly closed and insulated door would have an effectiveness $\eta=1$. Sometimes even an effectiveness of less than 0 can be encountered when an ill working air curtain would increase the heat flow.

Common values of the effectiveness are 0.85 to 0.95 for PVC strip doors and fast-sliding doors, while the values for air curtains range from very low to more than 0.7 [1]. Downing and Meffert [16] use a similar definition for the effectiveness of air curtains, but with air flow transfer rate instead of heat transfer rate (Eq.(6)). In this equation $\mathrm{Q}$ stands for the volumetric air flow rate 
$\left[\mathrm{m}^{3} / \mathrm{s}\right]$ across the doorway when a shielding device is present, $\mathrm{Q}_{\mathrm{open}}$ is the volumetric air flow rate $\left[\mathrm{m}^{3} / \mathrm{s}\right]$ when no device is present. Their experimental results for $\eta_{\text {air }}$ range from -1.58 to 0.85 .

$$
\eta_{\text {air }}=1-\frac{Q}{Q_{\text {open }}}
$$

To estimate the heat transfer rate through an open doorway different empirical relations can be found in literature. Hendrix et al. [17] compared some of these expressions with experimental results and found that the work by Gosney and Olama [18] gave the best results.

$q_{\text {open }}=0.221 A(g H)^{0.5}\left(h_{w}-h_{c}\right) \rho_{c}\left(1-\frac{\rho_{w}}{\rho_{c}}\right)^{0.5}\left(\frac{2}{1+\left(\rho_{c} / \rho_{w}\right)^{1 / 3}}\right)^{1.5}$

Here $A$ is the surface area of the doorway $\left[\mathrm{m}^{2}\right], h_{w}$ is the enthalpy of the warm air $[\mathrm{J} / \mathrm{kg}]$ and $\mathrm{h}_{\mathrm{c}}$ is the enthalpy of the cold air $[\mathrm{J} / \mathrm{kg}]$. Other relations for the heat transfer rate through an open door are found in [19-22].

By measuring the heat transfer through a doorway protected by an air curtain and comparing it with the heat transfer through an open doorway, the effectiveness of the air curtain can be determined.

\section{MEASUREMENTS OF HEAT TRANSFER THROUGH AN AIR CURTAIN}

\section{Measurement case description}

A series of experiments were performed on a vertically downwards blowing air curtain in a supermarket. The ACD is installed at a door that separates a cold room from the rest of the store. The device draws its air from the warm side of the store. The width of the door and jet is $2 \mathrm{~m}$. The width of the jet nozzle exit $b_{0}$ is $93 \mathrm{~mm}$ and the jet is blown straight down $\left(\alpha_{0}=0\right)$. The other geometrical properties are given in Figure 2. This figure shows a schematic 2D representation of the measurement case also used for simulations (these are discussed later). 
The air curtain can be set to 4 different velocity levels. The corresponding outlet velocities were measured using a hot-wire anemometer. The width of the air curtain device was $2 \mathrm{~m}$ and the velocity along the width was measured every $20 \mathrm{~cm}$ with a total of 10 measurement points. A large variation of the velocity was found along the width of the curtain. This was due to the construction of the air curtain. The air curtain device actually consisted of four double inlet centrifugal fans placed next to each other. At the centre of each fan the velocity reached a maximum which could be up to two times the average velocity of the curtain. The average velocity was calculated by taken the average of the ten measurement point along the width and ranged from $2.25 \mathrm{~m} / \mathrm{s}$ for the first level to $4.98 \mathrm{~m} / \mathrm{s}$ for level 4 . For the present study only these average velocities were used and the variations along the width of the curtain were neglected since only a $2 \mathrm{D}$ study was performed. It should be noted that the velocity profile could be of importance when studying 3D phenomena.

The temperature of the cold room is kept at a constant temperature of about $8^{\circ} \mathrm{C}$ by a cooling unit. Air is drawn from the centre of the cold room at the ceiling, is cooled down, and then reenters through perforated walls around the room. This way the cooled air first passes over the stored food products on the racks. Since all side walls have similar perforations, the cooled air is equally distributed in the cold room. During the measurements, the temperature in the warm area of the store was around $17^{\circ} \mathrm{C}$.

The air flow rate through the curtain was measured with a tracer gas decay method $[12,15,16,23,24]$. A concentration of $\mathrm{CO}_{2}$ tracer gas was released in the cooled room while the door was closed. A mixing fan ensured a homogenous distribution of the gas in the room. Then the door was opened and the air curtain was activated. The ventilation system of the cooling installation in the room ensured well mixed conditions in the room. From the exponential decay of the tracer gas concentration the air flow rate through the curtain can be estimated. If one can assume that all heat transfer is caused by mass transfer, the heat transfer rate can be calculated from the air flow rate, when assuming that the density of air is constant:

$q=\rho c_{p} Q \Delta T$ 


\section{Thermographic measurements}

To understand the behaviour of an air curtain, accurate knowledge of the temperature and velocity distribution is required. Many of the measurement equipment however provide point values (velocity: hot wire probe or LDA, temperature: thermocouple). Therefore, a large test matrix needs to be scanned, requiring a large number of sensors to map the distributions with sufficient resolution [17,24]. This can be very time consuming in the case of LDA [25]. To allow for a fast high resolution measurement of the temperature distribution, Neto et al. [26] proposed using infrared thermography. A thin paper sheet is placed transversely in the doorway and thermographic pictures are taken, allowing the visualisation of the temperature field across the door. Figure 3 shows the setup with paper sheet installed in the doorway of a cold store. This measurement technique has been successfully applied before to visualise flow in a complex fin array, [27]. These measurements were used to validate a CFD model. Figure 4 shows a thermographic image of a paper sheet near the outlet of the air curtain device. The top of the sheet is at $17 \mathrm{~cm}$ from the nozzle exit. On Figure 4 also the line is indicated which corresponds with the temperature profile in Figure 5. Uncertainty in the emissivity of the paper and reflections of the surroundings cause some of the irregularities encountered in the figure. Also the paper was attached to a frame (for stiffness). This frame has a finite thickness which could lead to some flow separation and thus an error on the measurements. Therefore the temperature profile of Figure 5 was taken at a height of $175 \mathrm{~cm}$, far enough from the frame edge to have less influence. Figure 5 shows the cold room temperature on the left and the warm room temperature on the right. The air curtain in the doorway is clearly visualized and shows a steep gradient from cold to warm room.

\section{NUMERICAL STUDY: RESULTS AND DISCUSSION}

A numerical study was performed using the CFD software Fluent ${ }^{\circledR}$. In this study only 2-D simulations were performed, in order to investigate the general behaviour of air curtains at the centre of the door. Most simulations assume steady-state conditions, except for the investigation of some unstable regimes. A pressure based segregated solver is used in combination with the standard k- $\varepsilon$ turbulence model [28]. For the fluid physical properties, the Boussinesq and Sutherland approximations are applied for the density and viscosity [29]. The discretized 
equations are solved using the $2^{\text {nd }}$ order upwind scheme. The SIMPLE algorithm was used for pressure-velocity coupling.

\section{Model validation}

In order to validate the CFD model for the ACD, the test case discussed in the previous section was simulated. The geometry used for the CFD validation is shown in Figure 2. The total length of the store in the model is $20 \mathrm{~m}$ and the jet nozzle is $0.093 \mathrm{~m}$ wide. Several grid-dependency tests using the Richardson extrapolation method [30] were performed. As a representative parameter for the Richardson extrapolation, the heat transfer rate through the air curtain was used. It was found that a grid of 154840 cells gave reasonable results. For this grid the solution for heat transfer through the curtain only deviated $3.4 \%$ from the grid independent solution. This was found to be acceptable. A structured grid with rectangular cells was used, fine near the air curtain (cell width $1 \mathrm{~cm}$ ) and courser near the outside boundaries (cell width up to $7 \mathrm{~cm}$ ).

In CFD simulations of an air curtain, the ACD is typically not included in full detail. The jet nozzle exit is modelled as a velocity inlet while the air return grille is an outlet of the mesh. The disadvantage of this approach, however, is that the temperature of the blown air has to be specified, and this temperature is equal to the temperature of the return air, which is a priori unknown. So instead, the interior of the air curtain device is included in the mesh and the velocity in the cells at the jet nozzle exit is specified. The temperature of the nozzle exit air will automatically be the same as the ACD incoming air temperature. For simplicity a uniform velocity profile is imposed to the cells at the nozzle, as well as values for the turbulent kinetic energy $\mathrm{k}\left[\mathrm{m}^{2} / \mathrm{s}^{2}\right]$ and turbulent dissipation rate $\varepsilon\left[\mathrm{m}^{2} / \mathrm{s}^{3}\right]$ calculated from the following equations:

$$
\begin{aligned}
& k_{0}=\frac{3}{2} I_{t 0}^{2} v_{0}^{2}=0.00375 v_{0}^{2} \\
& \varepsilon_{0}=\frac{k_{0}^{3 / 2}}{L_{\varepsilon}}=\frac{2 k_{0}^{3 / 2}}{b_{0}}
\end{aligned}
$$

The length scale for turbulent dissipation $L_{\varepsilon}$ is chosen as half of the nozzle width $b_{0} / 2$. The turbulence intensity $\mathrm{I}_{\mathrm{t}}$ is set to $5 \%$, a typical value. This value is not critical, since Guyonnaud et 
al. [25] verified that the turbulence intensity does not affect the air curtain performance, as long as it is in the range of 0 to $20 \%$. This is always the case for a commercial air curtain.

The cold room and warm room temperatures are specified on the left and right walls, as well as part of the fluid domain adjacent to those. Important to take into account in this model is the boundary condition for setting the temperatures of the surrounding rooms. Setting a fixed temperature in a number of cells adjacent to the walls gives satisfactory results, provided that the area, to which the temperature is set, is large enough compared to the total room area to make sure that the entire air flow of the circulation cell takes on the appropriate temperature. It was found that this area should fill about $50 \%$ of the room. Since the rooms are long enough this will not affect the air curtain and the heat transfer going through it. All other walls, including the roof and the ceiling are treated as adiabatic. The temperature of the cold room is $8^{\circ} \mathrm{C}$ while the surrounding temperature was $17^{\circ} \mathrm{C}$.

Costa et al. [2] also performed CFD simulations on an air curtain. He expressed the heat transfer rate through an air curtain using a Nusselt number. If $\mathrm{q}$ is assumed proportional to a convective heat transfer coefficient $h_{\text {conv }}\left[\mathrm{W} / \mathrm{m}^{2} \mathrm{~K}\right]$ and the interior-exterior temperature difference $\Delta \mathrm{T}=\mathrm{T}_{\mathrm{w}^{-}}$ $\mathrm{T}_{\mathrm{c}}$, then:

$q=h_{\text {conv }} H W \Delta T$

Where $\mathrm{W}$ is the door width $[\mathrm{m}]$. The Nusselt number represents the ratio of the convective heat transfer to the conductive heat transfer.

$N u=\frac{h_{c o n v} H}{\lambda}=\frac{q}{W} \frac{1}{\lambda \Delta T}$

Here $\lambda$ is the thermal conductivity of air $[\mathrm{W} / \mathrm{mK}]$ taken at the average temperature between cold and warm room.

To determine the convection coefficient $h_{\text {conv }}$ or the Nusselt number for the air curtain, the heat transfer through the air curtain has to be calculated from the CFD simulations. The heat transfer 
through a doorway can be seen as the sum of two components. The first term is called the advective heat transfer, which is the thermal energy carried away by the air flow crossing the doorway. The second component is the diffusive heat transfer, including molecular and turbulent diffusion mechanisms. To calculate the heat transfer through a doorway the following Eqs. (1315) are used. Eq. (13) is evaluated along a vertical line in the doorway.

$$
q=W \int_{0}^{H} v_{x} \rho c_{p}\left(T-T_{a v g}\right) d z-W \int_{0}^{H} \lambda_{\text {eff }} \frac{d T}{d x} d z
$$

Where

$$
\begin{aligned}
& T_{\text {avg }}=\frac{T_{w}+T_{c}}{2} \\
& \lambda_{\text {eff }}=\lambda+\lambda_{t}
\end{aligned}
$$

Here $v_{x}[\mathrm{~m} / \mathrm{s}]$ is the horizontal component of the velocity vector, $\lambda_{\text {eff }}[\mathrm{W} / \mathrm{mK}]$ is the effective thermal conductivity which is the sum of the molecular conductivity $\lambda$ and the turbulent conductivity $\lambda_{t}$. The temperature profile and temperature gradient across the doorway are important parameters in the estimation of the heat transfer through an air curtain as seen in Eq. (13). Comparison of the simulated temperature profile and thermographic images gave reasonable results. Figure 4 shows the comparison of the temperature field at the top of the doorway. Figure $4 \mathrm{a}$ shows the thermographic image, Figure $4 \mathrm{~b}$ is the result of the CFD simulation. A perfect match between both is difficult since thermography is accompanied by a lot of uncertainties, for example the uncertainty on the emissivity of the paper. Furthermore, reflections of the surroundings on the paper sheet could affect the measurement results significantly, and the presence of the bar on top of the paper to hold it firmly into place will affect the local flow field somewhat (this bar was needed to prevent the paper sheet from fluttering). Also 3D effects were not taken into account in the simulations and can have an impact on the results.

Figure 5 shows the temperature profile at a height of $1.75 \mathrm{~m}$ across the doorway. The figure shows a slight under prediction of the jet width. This is probably due to the non uniform outlet velocity of the air curtain device. Measurements of this outlet velocity showed that there can be a strong variation of the outlet velocity across the width of the air curtain (as mentioned before). 
Nevertheless there is a good visual agreement between temperature measurements and simulations so it can be concluded that the heat transfer through the air curtain can be predicted with satisfying accuracy.

To validate the CFD model further, tracer gas measurements were performed as described earlier and the heat transfer rate was deduced from these according to Eq. (8). Measurements were performed when no air curtain was present, when a PVC strip curtain was installed and for three different air curtain outlet velocities $(2.9 \mathrm{~m} / \mathrm{s}, 3.9 \mathrm{~m} / \mathrm{s}, 4.98 \mathrm{~m} / \mathrm{s})$. These measurements were then compared to the calculated heat transfer rates from CFD (Figure 6). A good agreement was found. Table 1 gives an overview of the boundary conditions during the measurements and used for the simulations.

\section{Flow patterns}

Eq. (3) calculates the minimal deflection modulus $D_{m, m i n}$ needed to avoid breakthrough according to Hayes and Stoecker [8]. This minimal deflection modulus only depends on the doorway geometry. For the case study with a door height of $2.27 \mathrm{~m}$ and a nozzle width of $0.093 \mathrm{~m}$ this corresponds with a $\mathrm{D}_{\mathrm{m}, \min }=0.1629$ and $\mathrm{v}_{0, \min }=1.68 \mathrm{~m} / \mathrm{s}$. These values are now compared to some simulation results.

Figure 7 shows the simulation results (streamline patterns) when no air curtain is present. The temperature at the cold side is $281 \mathrm{~K}$, temperature at the warm side is $290 \mathrm{~K}$. The flow pattern is dominated by natural convection. Warm air moves from the warm side to the cold side at the top of the doorway, while cold air enters the warm side at the bottom of the doorway. Since the velocity of the air curtain $\mathrm{v}_{0}$ is $0 \mathrm{~m} / \mathrm{s}$ the deflection modulus will also be zero. The heat transfer rate through the curtain is $5960 \mathrm{~W}$.

A similar pattern is found in Figure 8. Here the outlet velocity of the curtain $\mathrm{v}_{0}=1.3 \mathrm{~m} / \mathrm{s}$. This corresponds with $\mathrm{D}_{\mathrm{m}}=0.0971$. This is clearly lower than the calculated minimal deflection modulus. Since the outlet momentum of the air curtain is too low due to the low air velocity, breakthrough occurs. Again warm air enters the cold room at the top of the doorway and cold air leaves the cold room at the bottom. The bulk transport of air is accompanied by a large amount of heat transfer. The heat transfer found for this case equals $5580 \mathrm{~W}$ which is the same order of magnitude as an open doorway with now protective device. 
Increasing the outlet velocity to values higher than $v_{0, \text { min }}$ does not always guarantee a good working air curtain. When the outlet velocity is increased, an unstable regime can occur. This is shown in Figure 9. In this transient regime, the air curtain alternates between reaching the ground and breakthrough. This implies that transient simulations have to be performed to reach convergence and a number of periods have to be simulated, indicating the periodic behaviour. Figure 9 shows the solution at a fixed point in time. Since the air curtain is unstable this solution changes in time. The influence of natural convection on the flow pattern is of the same order of magnitude as air jet momentum. This causes the three circulation cells. In the warm room (right hand side) the two effects (natural convection and jet momentum) collaborate to form one circulation cell. In the cold room the two effects counteract, resulting in two circulation cells. The applied nozzle exit velocity was $1.8 \mathrm{~m} / \mathrm{s}$. This gives a deflection modulus of 0.1861 . Although this value is higher than the minimal deflection modulus according to Hayes and Stoecker [8] no stable working air curtain is found. It is clear that a safety factor on the calculated $\mathrm{D}_{\mathrm{m} \text {,min }}$ and $\mathrm{v}_{0, \min }$ is in place. The heat transfer through the doorway is still high: $5680 W$.

For higher air velocities the jet momentum dominates, resulting in a stable air curtain. In Figure 10 the air curtain nozzle exit velocity $\mathrm{v}_{0}$ equals $3.9 \mathrm{~m} / \mathrm{s}$ and the corresponding deflection modulus is 0.874 . This is clearly higher than $\mathrm{D}_{\mathrm{m} \text {,min. }}$. The heat transfer for this case is limited to $2212 \mathrm{~W}$. From the previous simulations it is found that the expression of a minimal deflection modulus for stable air curtain according to Hayes and Stoecker [8] not always holds. More simulations were conducted to investigate this further. Table 2 gives on overview of the simulation boundary conditions and the resulting deflection moduli. For each case it is indicated if the air curtain is stable, unstable or if breakthrough occurs. From this table its clear that $\mathrm{D}_{\mathrm{m} \text {,min }}$ does not suffice to predict a stable curtain. When the temperature difference between the cold and warm room is $25^{\circ} \mathrm{C}$, the deflection modulus should even be two times $\mathrm{D}_{\mathrm{m} \text {,min }}$ in order to have a stable curtain. Therefore a suitable safety factor needs to be taken into account also to compensate for external effects such as traffic through the doorway, three dimensional effects, the influence of wind or an imbalance in ventilation flows. At least a safety factor of 2 for the deflection modulus $\mathrm{D}_{\mathrm{m}}$ or a factor $\sqrt{ } 2$ for the velocity $\mathrm{v}_{0}$ should be applied. 


\section{Heat transfer correlation}

The air curtain outlet velocity determines the stability of the air curtain. When the velocity is too low and breakthrough occurs, the heat transfer is high. For the present case study a velocity of 2 $\mathrm{m} / \mathrm{s}$ is needed to attain a stable curtain. For this velocity the heat transfer rate is minimal (Figure 11) and consequently the effectiveness reaches a maximum (Figure 12). For higher velocities the heat transfer increases linearly. This is due to the higher amount of mixing at higher jet velocities. Similar results were also presented in literature $[2,10,15]$.

In order to obtain an expression for the heat transfer through the air curtain, independent of the chosen geometry, a series of simulations was performed using some geometrical variations of the studied measurement case. The range of used parameters is given in Table 3.

Hayes and Stoecker [8] suggested that the dimensionless group $\mathrm{Nu} / \mathrm{RePr}$ is independent of $\mathrm{D}_{\mathrm{m}}$ for stable air curtains. The Reynolds number Re can be calculated from Eq. (16) where $\mu$ is the dynamic viscosity of air. $\rho_{0}$ and $\mu$ are evaluated at the ACD nozzle exit temperature.

$$
\operatorname{Re}=\frac{\rho_{0} b_{0} v_{0}}{\mu}
$$

Simulation results of this study confirm this suggestion. Because of this conclusion, there are only two dependent parameters left, namely the $\mathrm{H} / \mathrm{b}_{0}$ ratio and $\alpha_{0}$. For this study the outlet angle $\alpha_{0}$ was kept constant at $0^{\circ}$. Figure 13 shows the linear dependency between $\mathrm{Nu} / \mathrm{RePr}$ and $\mathrm{H} / \mathrm{b}_{0}$ for $\alpha_{0}=0^{\circ}$.

Linear regression of this data yields expression (17), with a coefficient of regression $\mathrm{R}^{2}=0.9843$. This expression predicts the heat transfer rate for all simulations with an error of less than $9 \%$. Expression (17) is valid for downwards blowing single-jet air curtains for cold rooms with $\alpha_{0}=$ $0^{\circ}$ and within the range of parameters given by Table 3 and only when the jet outlet momentum is high enough to ensure a stable air curtain. Table 2 indicates that a stable air curtain is assured when $\mathrm{D}_{\mathrm{m}, \mathrm{min}}$ is calculated according to Eqs. (3) and (4) and when a safety factor of 2 is applied.

$$
\frac{N u}{\operatorname{Re} \operatorname{Pr}}=0.008379 \frac{H}{b_{0}}+0.06600
$$


Note that the use of a safety factor is also necessary to cope with other disturbances such as wind pressure and traffic passing through the curtain. These factors are harder to predict and can change in time. Therefore a continuous check of the air curtain performance is suggested for example by monitoring the cooling load of the cold room and comparing it to the design cooling load.

\section{CONCLUSIONS}

A numerical model for a downwards blowing air curtain was built and verified through experiments, including thermographic imaging and tracer gas decay tests.

The maximum effectiveness of an air curtain occurs when the outlet momentum is just large enough to ensure that the air jet is stable and reaches the opposite side. The analytical expressions by Hayes and Stoecker [8] are fairly accurate in predicting this minimal required jet momentum, although simulations showed that a safety factor needs to be taken into account. When operating at this optimal condition, an air curtain is able to accomplish an effectiveness of up to about $80 \%$. This means it reduces the heat transfer to $20 \%$ of the corresponding value without an air curtain.

To estimate the actual heat transfer rate through a downwards blowing air curtain, a linear equation for the dimensionless group $\mathrm{Nu} / \mathrm{RePr}$ is suggested (Eq. (17)), as a function of the ratio $\mathrm{H} / \mathrm{b}_{0}$. This equation was derived for the range of parameters shown in Table 3 and a jet discharge angle $\alpha_{0}=0^{\circ}$. It is only valid when the outlet momentum is sufficient to ensure a stable operation of the air curtain.

\section{NOMENCLATURE}

$\begin{array}{ll}A & \text { Area of the doorway, } \mathrm{m}^{2} \\ \mathrm{~b}_{0} & \text { Jet nozzle width, } \mathrm{m} \\ \mathrm{c}_{\mathrm{p}} & \text { Specific heat of air, J/kgK } \\ \mathrm{D}_{\mathrm{m}} & \text { Deflection modulus } \\ \mathrm{g} & \text { Gravitational acceleration, } \mathrm{m} / \mathrm{s}^{2} \\ \mathrm{Gr} & \text { Grashof number } \\ \mathrm{H} & \text { Height of the doorway, } \mathrm{m} \\ \mathrm{h}_{\mathrm{c}} & \text { Enthalpy of cold air, J/kg } \\ \mathrm{h}_{\mathrm{conv}} & \text { Convective heat transfer coefficient, W/m } / \mathrm{m}^{2} \mathrm{~K} \\ \mathrm{~h}_{\mathrm{w}} & \text { Enthalpy of warm air, } / \mathrm{kg} \\ \mathrm{I}_{\mathrm{t}} & \text { Turbulence intensity } \\ \mathrm{k} & \text { Turbulent kinetic energy, } \mathrm{m}^{2} / \mathrm{s}^{2} \\ \mathrm{~L}_{\varepsilon} & \text { Length scale for turbulent dissipation, } \mathrm{m}\end{array}$




$\begin{array}{ll}\mathrm{Nu} & \text { Nusselt number } \\ \Delta \mathrm{p} & \text { Pressure difference across the opening, Pa } \\ \Delta \mathrm{p}_{\mathrm{a}} & \text { Auxiliary pressure, } \mathrm{Pa} \\ \Delta \mathrm{p}_{\mathrm{s}} & \text { Stack pressure, Pa } \\ \mathrm{Pr} & \text { Prandtl number } \\ \mathrm{q} & \text { Heat transfer rate through the opening, W } \\ \mathrm{Q} & \text { Transfer rate of air through the opening, } \mathrm{m}^{3} / \mathrm{s} \\ \mathrm{Re} & \text { Reynolds number, Eq. (16) } \\ \mathrm{Ri} & \text { Richardson number, Eq. (2) } \\ \mathrm{T} & \text { Air temperature, K } \\ \Delta \mathrm{T} & \text { Temperature difference between the hot and cold zone, K } \\ \mathrm{V} & \text { Jet velocity, m/s } \\ \mathrm{V}_{\mathrm{X}} & \text { Horizontal component of velocity vector, } \mathrm{m} / \mathrm{s} \\ \mathrm{W} & \text { Width of the doorway and the air curtain, } \mathrm{m} \\ \mathrm{X} & \mathrm{x} \text { coordinate, horizontal direction, } \mathrm{m} \\ \mathrm{z} & \mathrm{z} \text { coordinate, vertical direction, } \mathrm{m}\end{array}$

Greek symbols

$\begin{array}{ll}\alpha & \text { Jet angle, }^{\circ} \\ \beta & \text { Thermal expansion coefficient, } \mathrm{K}^{-1} \\ \varepsilon & \text { Turbulent dissipation rate, } \mathrm{m}^{2} / \mathrm{s}^{3} \\ \eta & \text { Effectiveness } \\ \lambda & \text { Thermal conductivity of air, } \mathrm{W} / \mathrm{mK} \\ \mu & \text { Dynamic viscosity of air, } \mathrm{Pa} \mathrm{s} \\ \rho & \text { Density of air, } \mathrm{kg} / \mathrm{m}^{3}\end{array}$

Subscripts

0

avg

c

At jet nozzle

Average

conv Convective

eff Effective

$\mathrm{f} \quad$ At the end of the jet (impingement)

min Minimum value to ensure stability

open Open door

$\mathrm{t} \quad$ Turbulent

w Warm air

\section{REFERENCES}

[1] ASHRAE Handbook - Refrigeration 2010, chapter 24 Refrigerated-facility loads, pp. 24.124.8 .

[2] Costa, J.J., Oliveira, L.A., and Silva, M.C.G., Energy savings by aerodynamic sealing with a downward-blowing plane air curtain - A numerical approach, Energy and Buildings vol. 38, no. 10, pp. 1182-1193, 2006. 
[3] Yu, K.-z., Ding, G.-1., and Chen, T.-j. Simulation of air curtains for vertical display cases with a two-fluid model, Applied Thermal Engineering, vol. 27, no.14-15, pp. 2583-2591, 2007. [4] Steeman, H.-J., Janssens, A., Carmeliet, J., and De Paepe, M., Modelling indoor air and hygrothermal wall interaction in building simulation: Comparison between CFD and a wellmixed zonal model, Building and Environment, vol. 44, no. 3, pp. 572-583, 2009.

[5] Steeman, H.-J., Van Belleghem, M., Janssens, A., and De Paepe, M., Coupled simulation of heat and moisture transport in air and porous materials for the assessment of moisture related damage. Building and Environment, vol. 44, no. 10, pp. 2176-2184, 2009.

[6] Van Belleghem, M., Steeman, H.-J., Steeman, M., Janssens, A., and De Paepe, M., Sensitivity analysis of CFD coupled non-isothermal heat and moisture modelling. Building and Environment, vol. 45, no. 11, pp. 2485-2496, 2010.

[7] Van Belleghem, M., Steeman, M., Willockx, A., Janssens, A., and De Paepe, M., Benchmark experiments for moisture transfer modelling in air and porous materials. Building and Environment, vol. 46, no. 4, pp. 884-898, 2011.

[8] Hayes, F.C., and Stoecker, W.F., Heat transfer characteristics of air curtains, Ashrae Journal, Vol. 11, no. 6, 1969.

[9] Hayes, F.C., and Stoecker W.F., Design data for air curtains, Ashrae Journal, vol. 11, no. 6, 1969.

[10] Chen, Y.-G., and Yuan, X.-L., Experimental study of the performance of single-band air curtains for a multi-deck refrigerated display cabinet, Journal of Food Engineering, vol. 69, no. 3, pp. 261-267, 2005.

[11] Chen, Y.-G., and Yuan, X.-L., Simulation of a cavity insulated by a vertical single band cold air curtain, Energy Conversion and Management, vol. 46, no. 11-12, pp.1745-1756, 2005. [12] Foster, A.M., Swain, M.J., Barrett, R., D'Agaro, P., and James, S.J., Effectiveness and optimum jet velocity for a plane jet air curtain used to restrict cold room infiltration,

International Journal of Refrigeration, vol. 29, no. 5, pp. 692-699, 2006.

[13] Sirén, K., Technical dimensioning of a vertically upwards-blowing air curtain -part I, Energy and Buildings, vol. 35, no. 7, pp. 681-695, 2003.

[14] Sirén, K., Technical dimensioning of a vertically upwards-blowing air curtain--part II, Energy and Buildings, vol. 35, no. 7, pp. 697-705, 2003.

[15] Foster, A.M., Swain, M.J., Barrett, R., D'Agaro, P., Ketteringham, L.P., and James, S.J., Three-dimensional effects of an air curtain used to restrict cold room infiltration, Applied Mathematical Modelling, vol. 31, no. 6, pp. 1109-1123, 2007.

[16] Downing, C.C., and W.A. Meffert, Effectiveness of cold-storage door infiltration protective devices, ASHRAE Transactions, vol. 99, no.2, pp.356-366, 1993.

[17] Hendrix, W.A., Henderson, D.R., and Jackson, H.Z., Infiltration heat gains through cold storage room doorways, ASHRAE Transactions, vol. 95, no. 2, pp. 1158-1168, 1989.

[18] Gosney, W.B., and Olama, H.A.L., Heat and enthalpy gains through cold room doorways, Proceedings of the Institute of Refrigeration, vol. 72, pp. 31-41, 1975.

[19] Brown, W.G., and Solvason, K.R., Natural convection through rectangular openings in partitions--1: Vertical partitions, International Journal of Heat and Mass Transfer, vol. 5, no. 9, pp. 859-868, 1962.

[20] Tamm, W., Kalterveluste durch kuhlraumoffnungen. Kaltetechnik-Klimatisierung, vol. 18, pp. 142-144, 1966.

[21] Fritzsche, C., and Lilienblum, W., Neue messengun zur bestimmung der kalterluste an kuhlraumturen, Kaltetechnik-Klimatiserung, vol. 20, pp. 279-286, 1968. 
[22] Jones, B.W., Beck, B.T., and Steele J.P., Latent loads in low humidity rooms due to moisture, ASHRAE Transactions, vol. 89, pp. 35-55, 1983.

[23] Chen, P., Cleland, D.J., Lovatt, S.J., and Bassett M.R., An empirical model for predicting air infiltration into refrigerated stores through doors, International Journal of Refrigeration, vol. 25, no. 6, pp. 799-812, 2002.

[24] Foster, A.M., Swain, M.J., Barrett, R., and James, S.J., Experimental verification of analytical and CFD predictions of infiltration through cold store entrances, International Journal of Refrigeration, vol. 26, no. 8, pp. 918-925, 2003.

[25] Guyonnaud, L., Solliec, C., de Virel, M.D., and Rey, C. Design of air curtains used for area confinement in tunnels, Experiments in Fluids, vol. 28, no. 4, pp.377-384, 2000.

[26] Neto, L.P.C., Silva, M.C.G., and Costa J.J., On the use of infrared thermography in studies with air curtain devices, Energy and Buildings, vol. 38, no. 10, pp. 1194-1199, 2006.

[27] T'Joen, C., Willockx, A., and De Paepe, M., Flow visualisation within inclined louvered fins, Journal of Heat Transfer - Transactions of the ASME, vol. 129, pp. 934-934, 2007.

[28] Launder, B.E., and Spalding, D.B., The numerical computation of turbulent flows. Computer Methods in Applied Mechanics and Engineering vol.3, no.2, pp. 269-289, 1974.

[29] Ansys Inc. Fluent user's guide Version 12.0, 2009

[30] Roache, P.J., Quantification of uncertainty in computational fluid dynamics, Annual Review of Fluid Mechanics, vol. 29, pp. 123-160, 1997. 
Table 1 Boundary conditions and heat transfer results for the air curtain measurements ( $\left.\mathrm{q}_{\text {measurement }}\right)$ and simulations $\left(\mathrm{q}_{\mathrm{CFD}}\right)$

\begin{tabular}{llllll}
\hline $\mathrm{v}_{0}[\mathrm{~m} / \mathrm{s}]$ & $\mathrm{T}_{\mathrm{w}}[\mathrm{K}]$ & $\mathrm{T}_{\mathrm{c}}[\mathrm{K}]$ & $\Delta \mathrm{T}[\mathrm{K}]$ & $\mathrm{q}_{\text {measurement }}[\mathrm{W}]$ & $\mathrm{q}_{\mathrm{CFD}}[\mathrm{W}]$ \\
\hline 4.98 & 292.5 & 284.5 & 8 & 2443 & 2530 \\
3.90 & 290.3 & 280.6 & 9.7 & 2262 & 2364 \\
2.90 & 289.7 & 281.2 & 8.5 & 1375 & 1524 \\
0 & 289.7 & 281.2 & 8.5 & 5548 & 5440 \\
PVC strips & 289.7 & 281.2 & 8.5 & 675 & - \\
\hline
\end{tabular}


Table 2 Overview of boundary conditions for some simulations and the resulting flow regime

\begin{tabular}{|c|c|c|c|c|c|c|c|}
\hline $\mathrm{H}[\mathrm{m}]$ & $\mathrm{b}_{0}[\mathrm{~m}]$ & $\mathrm{T}_{\mathrm{c}}[\mathrm{K}]$ & $\mathrm{T}_{\mathrm{w}}[\mathrm{K}]$ & $\mathrm{v}_{0}$ & $\mathrm{D}_{\mathrm{m}, \min }$ & $\mathrm{D}_{\mathrm{m}}$ & Flow regime \\
\hline \multirow[t]{3}{*}{2.27} & 0.093 & 281 & 290 & 1.6 & 0.1629 & 0.1471 & Breakthrough \\
\hline & & & & 1.8 & & 0.1861 & Unstable \\
\hline & & & & 2 & & 0.2298 & Stable \\
\hline \multirow[t]{4}{*}{2.27} & 0.0465 & 281 & 290 & 2.3 & 0.1507 & 0.1519 & Breakthrough \\
\hline & & & & 2.5 & & 0.1795 & Unstable \\
\hline & & & & 2.7 & & 0.2094 & Unstable \\
\hline & & & & 2.9 & & 0.2415 & Stable \\
\hline \multirow[t]{4}{*}{1.135} & 0.093 & 281 & 290 & 0.8 & 0.1780 & 0.1471 & Breakthrough \\
\hline & & & & 0.9 & & 0.1861 & Unstable \\
\hline & & & & 1.1 & & 0.2780 & Unstable \\
\hline & & & & 1.2 & & 0.3309 & Stable \\
\hline \multirow[t]{4}{*}{1.135} & 0.0465 & 281 & 290 & 1.1 & 0.1629 & 0.139 & Breakthrough \\
\hline & & & & 1.2 & & 0.1654 & Unstable \\
\hline & & & & 1.4 & & 0.2252 & Unstable \\
\hline & & & & 1.6 & & 0.2941 & Stable \\
\hline \multirow[t]{4}{*}{2.27} & 0.093 & 273 & 298 & 2.8 & 0.1629 & 0.1575 & Breakthrough \\
\hline & & & & 3.0 & & 0.1808 & Unstable \\
\hline & & & & 4.0 & & 0.3214 & Unstable \\
\hline & & & & 4.2 & & 0.3544 & Stable \\
\hline
\end{tabular}


Table 3 Range of parameters used in simulations

\begin{tabular}{ll}
\hline Parameter & Range \\
\hline Outlet velocity $\mathrm{v}_{0}$ & $0-8 \mathrm{~m} / \mathrm{s}$ \\
Outlet width $\mathrm{b}_{0}$ & $0.047-0130 \mathrm{~m}$ \\
Door height $\mathrm{H}$ & $1.14-4.54 \mathrm{~m}$ \\
Temperature difference $\Delta \mathrm{T}$ & $9-25 \mathrm{~K}$ \\
\hline
\end{tabular}




\section{List of Figures}

Figure 1. Schematic representation of an air curtain with some geometrical definitions: the inlet angle $\alpha_{0}$, the jet impingement angle $\alpha_{\mathrm{f}}$, the door height $\mathrm{H}$.

Figure 2. Geometrical properties of the test site (cross section)

Figure 3. Paper sheet used in doorway for thermographic pictures.

Figure 4. Comparison between infrared thermography and CFD simulations of an air curtain. The picture corresponds to the upper paper sheet in Figure 3.

Figure 5. Comparison of the measured temperature profile $(\diamond)$ and the simulated profile $(\circ)$ across the doorway at a height of $1.75 \mathrm{~m}$.

Figure 6. Comparison of the heat flow rate between simulations and measurement results. PVC strip curtains, - CFD simulations, heat transfer calculated from concentration decay measurements.

Figure 7. Streamline patterns when no air curtain is present driven by natural convection, $\mathrm{v}_{0}=0$ $\mathrm{m} / \mathrm{s}, \mathrm{T}_{\mathrm{c}}=281 \mathrm{~K}, \mathrm{~T}_{\mathrm{w}}=290 \mathrm{~K}$. One large circulation cell forms with warm air moving from the warm side to the cold side at the top of the doorway while cold air is leaving the cooled room at the bottom.

Figure 8. Streamline patterns with air curtain breakthrough, $\mathrm{v}_{0}=1.3 \mathrm{~m} / \mathrm{s}, \mathrm{T}_{\mathrm{c}}=281 \mathrm{~K}, \mathrm{~T}_{\mathrm{w}}=290 \mathrm{~K}$.

Figure 9. Streamline pattern for unstable air curtain, $\mathrm{v}_{0}=1.8 \mathrm{~m} / \mathrm{s}, \mathrm{T}_{\mathrm{c}}=281 \mathrm{~K}, \mathrm{~T}_{\mathrm{w}}=290 \mathrm{~K}$. Apparently three circulation cells occur.

Figure 10. Streamline pattern for stable air curtain with adequate shielding, $v_{0}=3.9 \mathrm{~m} / \mathrm{s}, \mathrm{T}_{\mathrm{c}}=281 \mathrm{~K}$, $\mathrm{T}_{\mathrm{w}}=290 \mathrm{~K}$.

Figure 11. Heat transfer rate as function of the air curtain velocity. $\mathrm{T}_{\mathrm{c}}=281 \mathrm{~K}, \mathrm{~T}_{\mathrm{w}}=290 \mathrm{~K}, \mathrm{~W}=2 \mathrm{~m}$.

Figure 12. Effectiveness as function of the air curtain velocity. $\mathrm{T}_{\mathrm{c}}=281 \mathrm{~K}, \mathrm{~T}_{\mathrm{w}}=290 \mathrm{~K}, \mathrm{~W}=2 \mathrm{~m}$.

Figure 13. Dimensionless heat transfer as function of the geometric ratio $\mathrm{H} / \mathrm{b}_{0}$, for varying parameters according to Table 3 . 
Figure 1

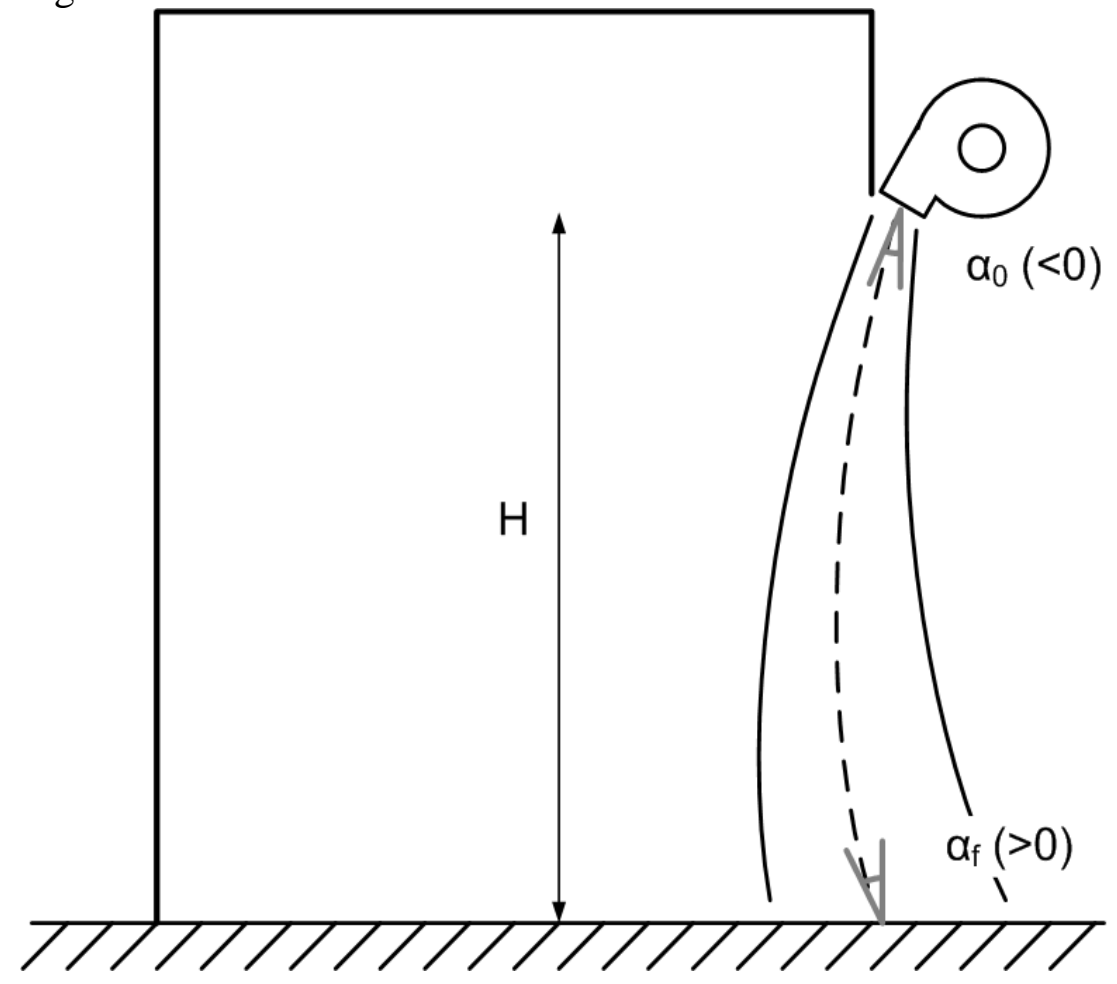


Figure 2

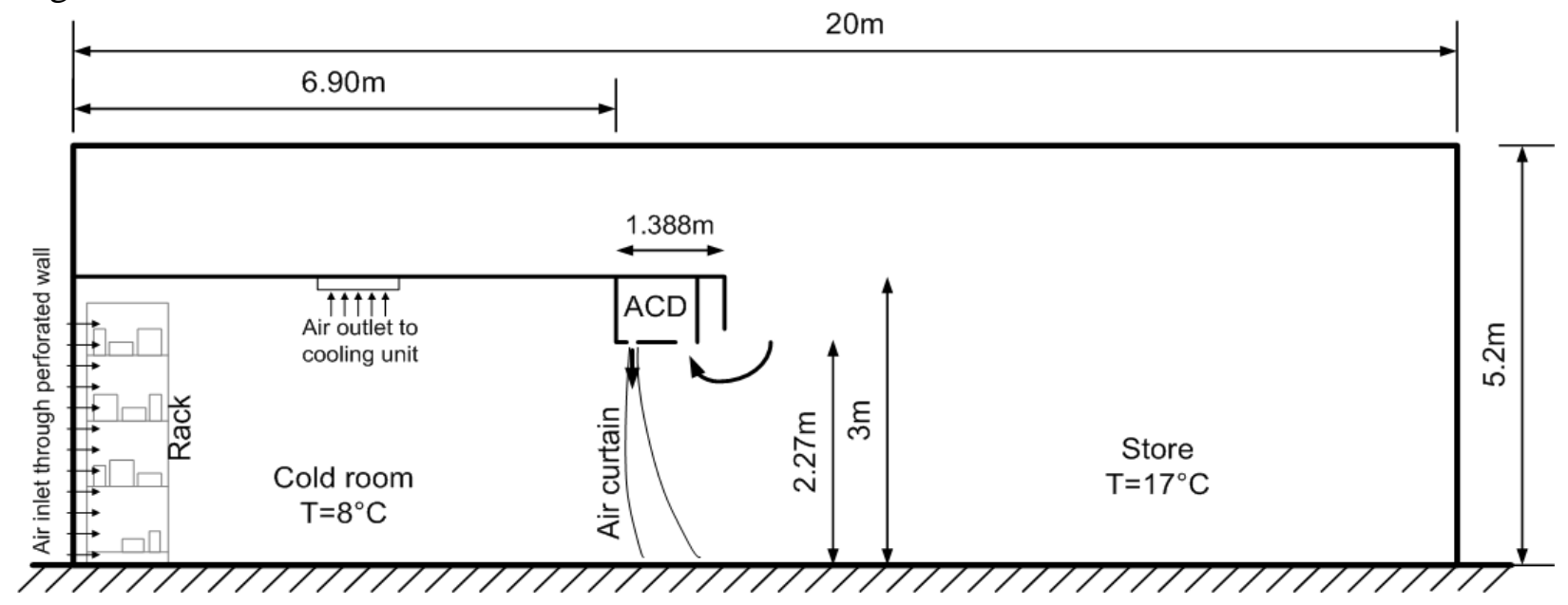


Figure 3

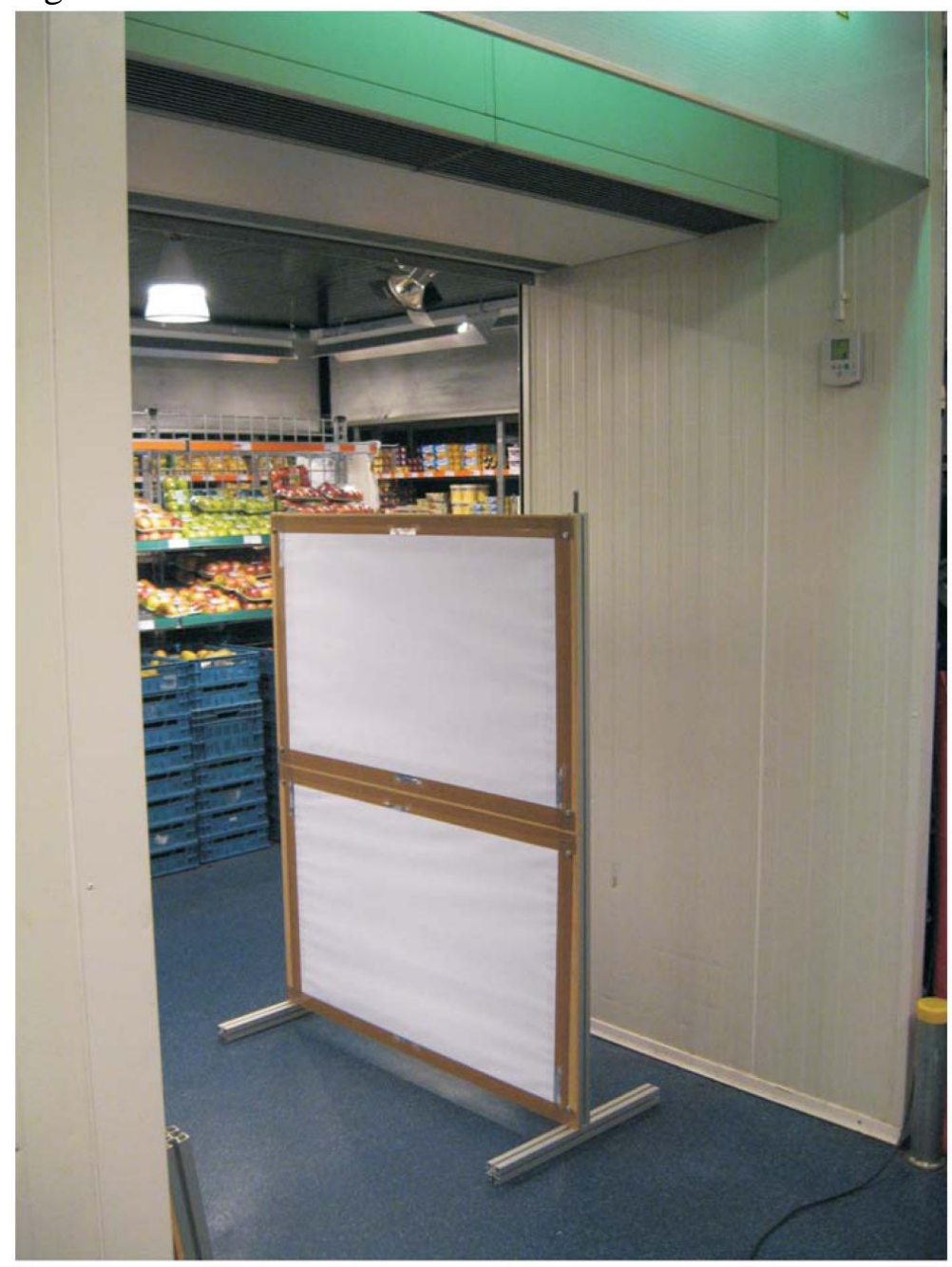


Figure 4
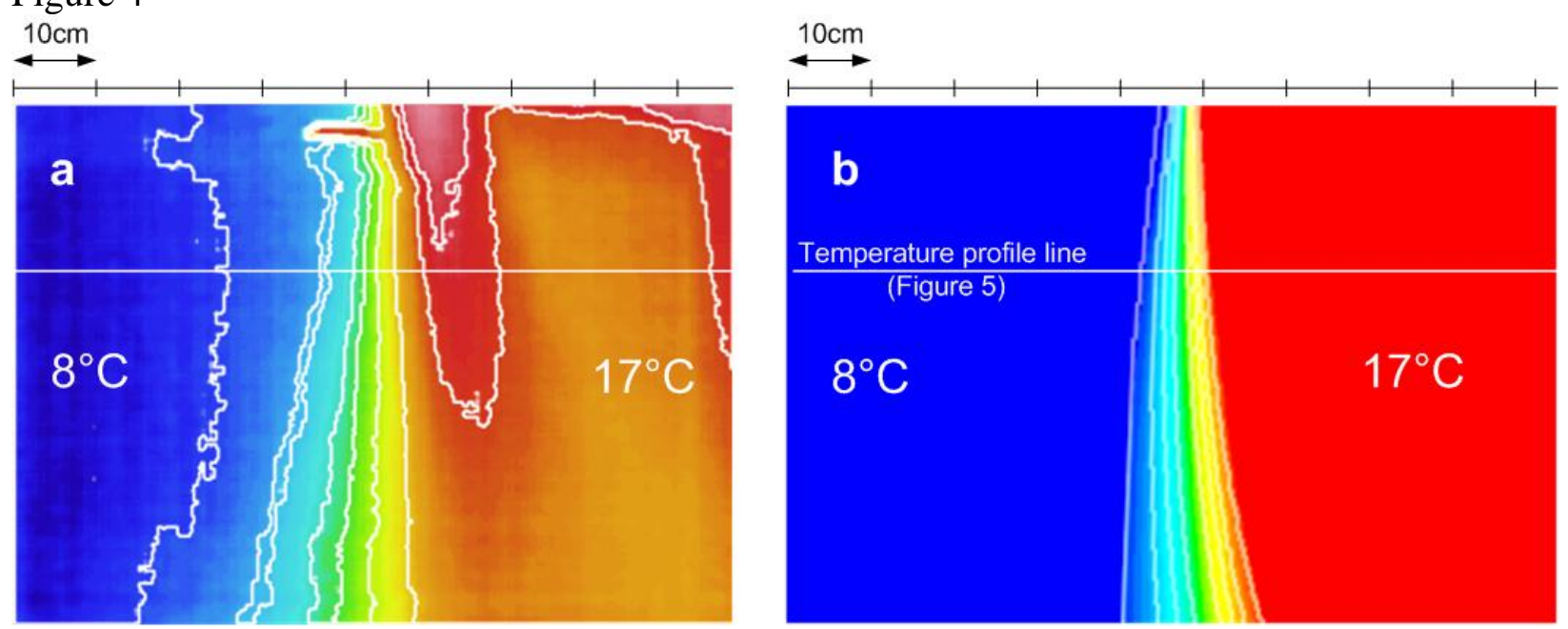
Figure 5

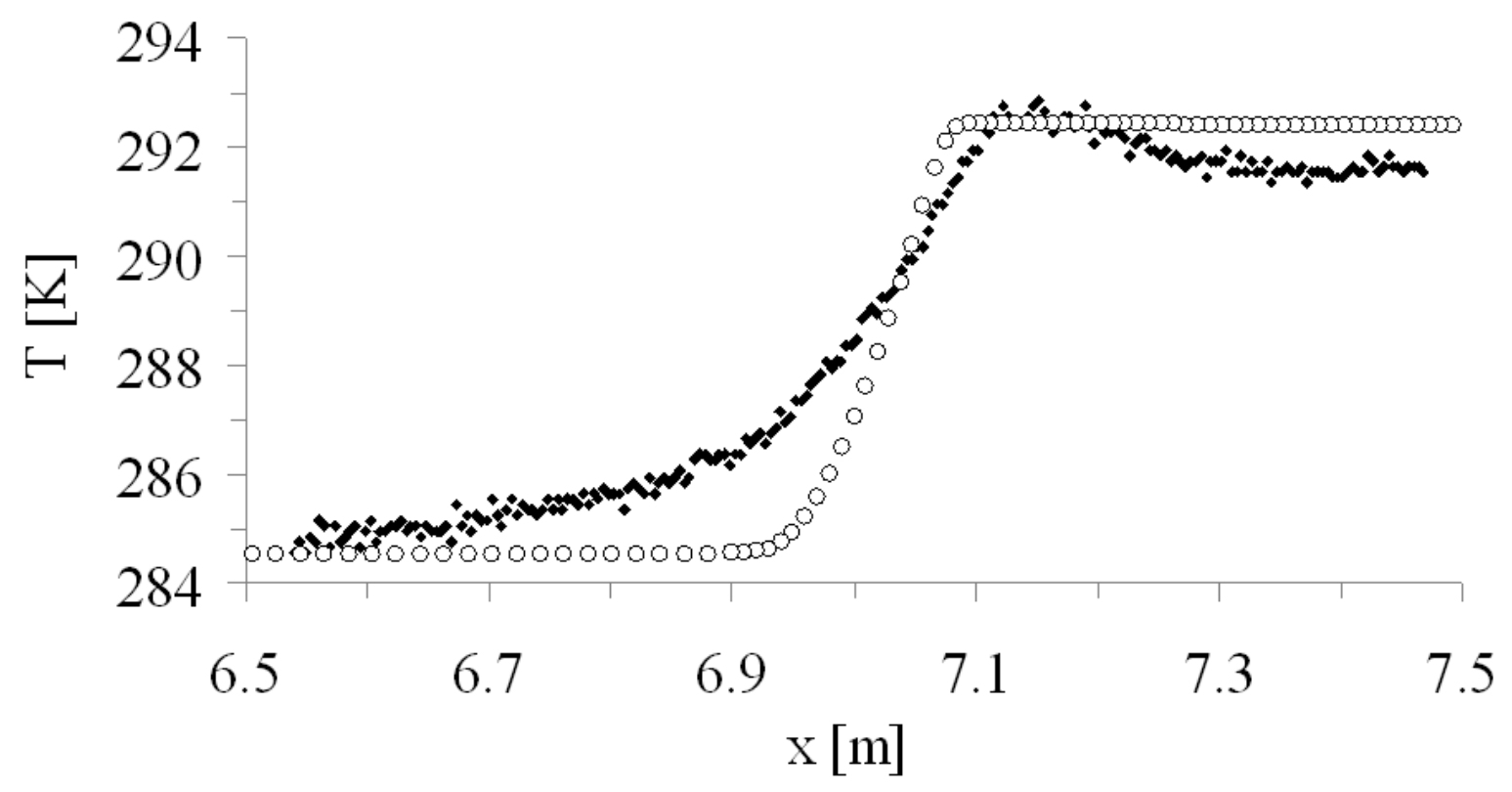


Figure 6

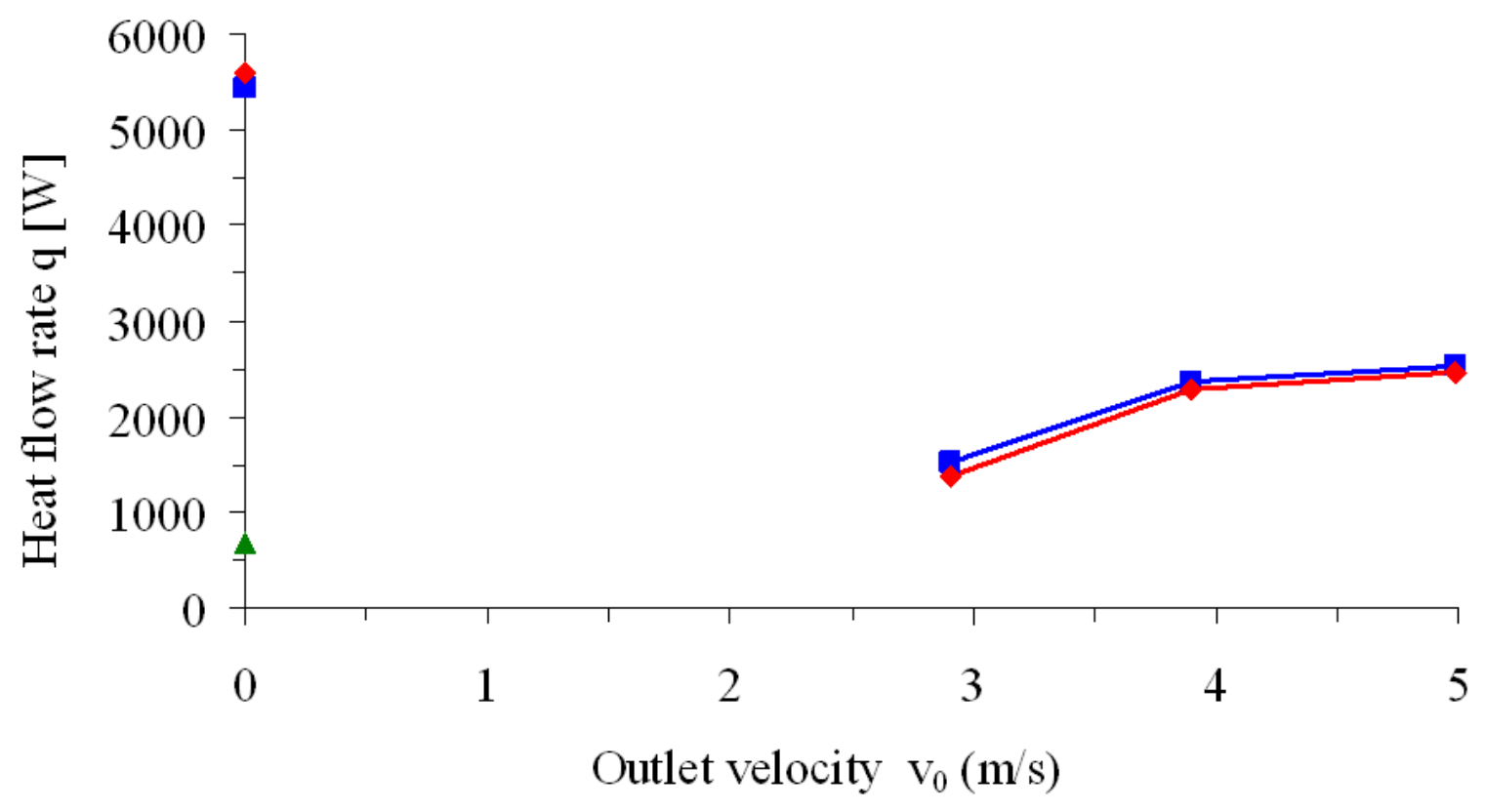


Figure 7

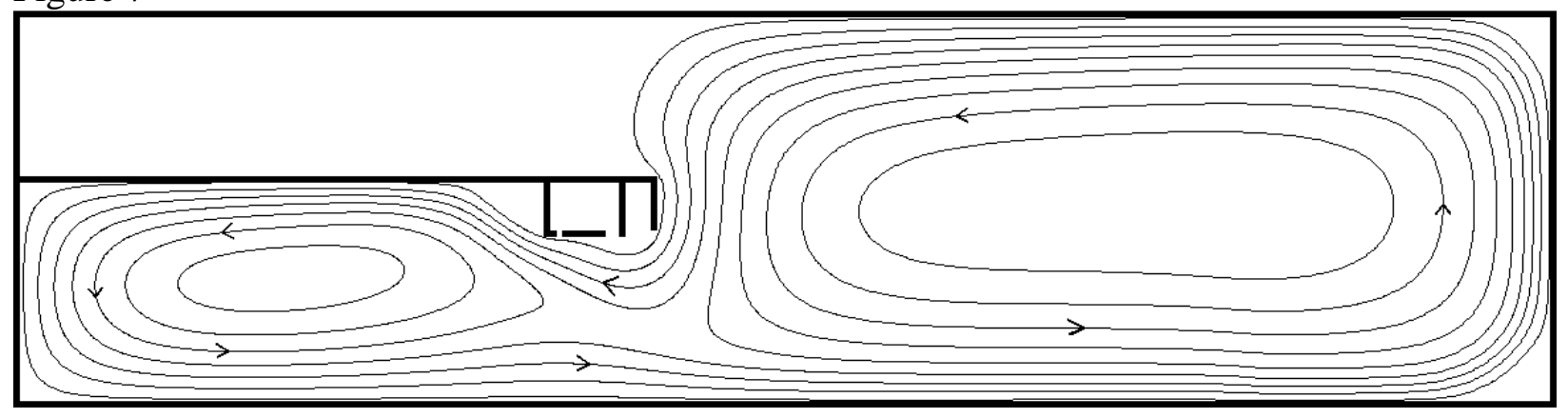

Figure 8

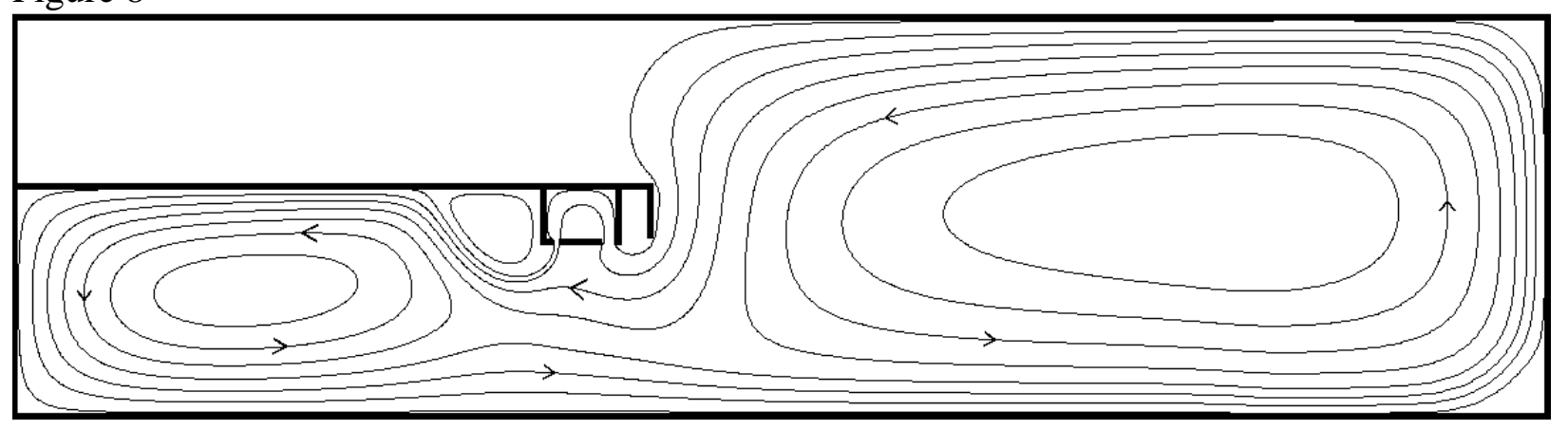

Figure 9

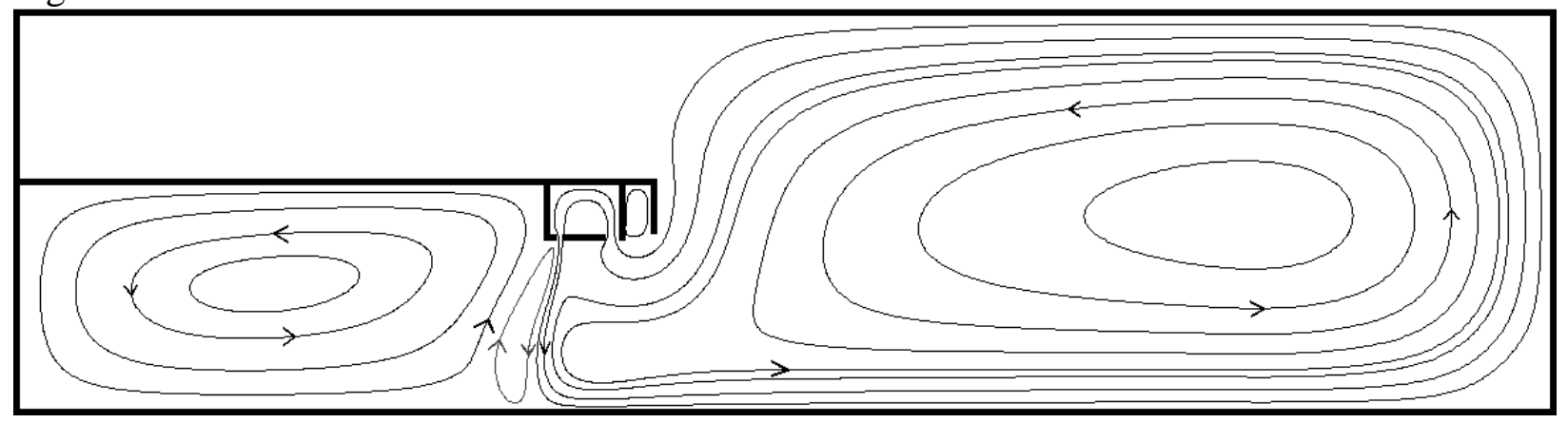

Figure 10

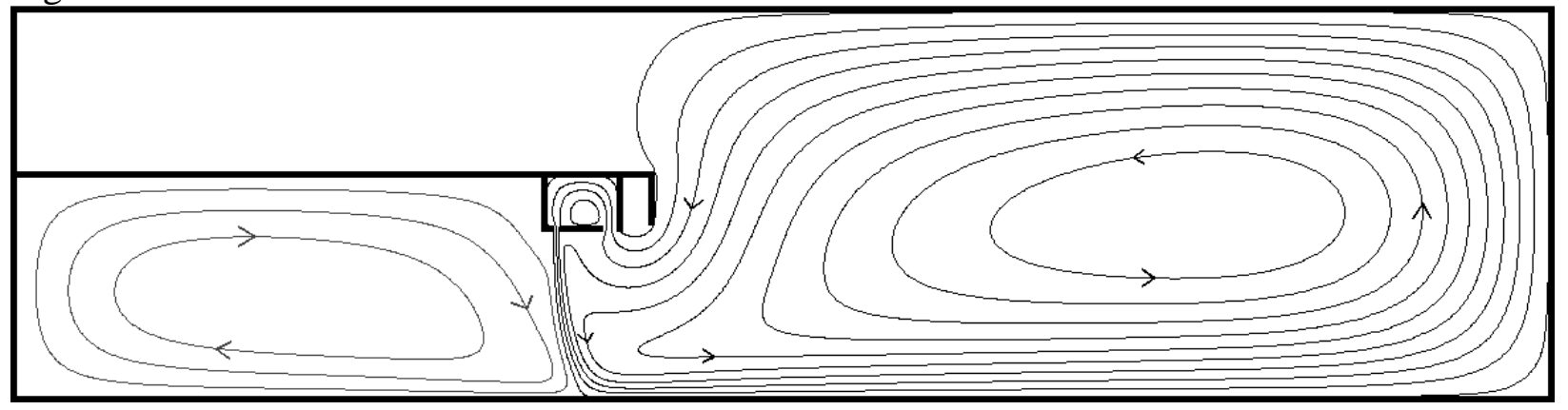


Figure 11

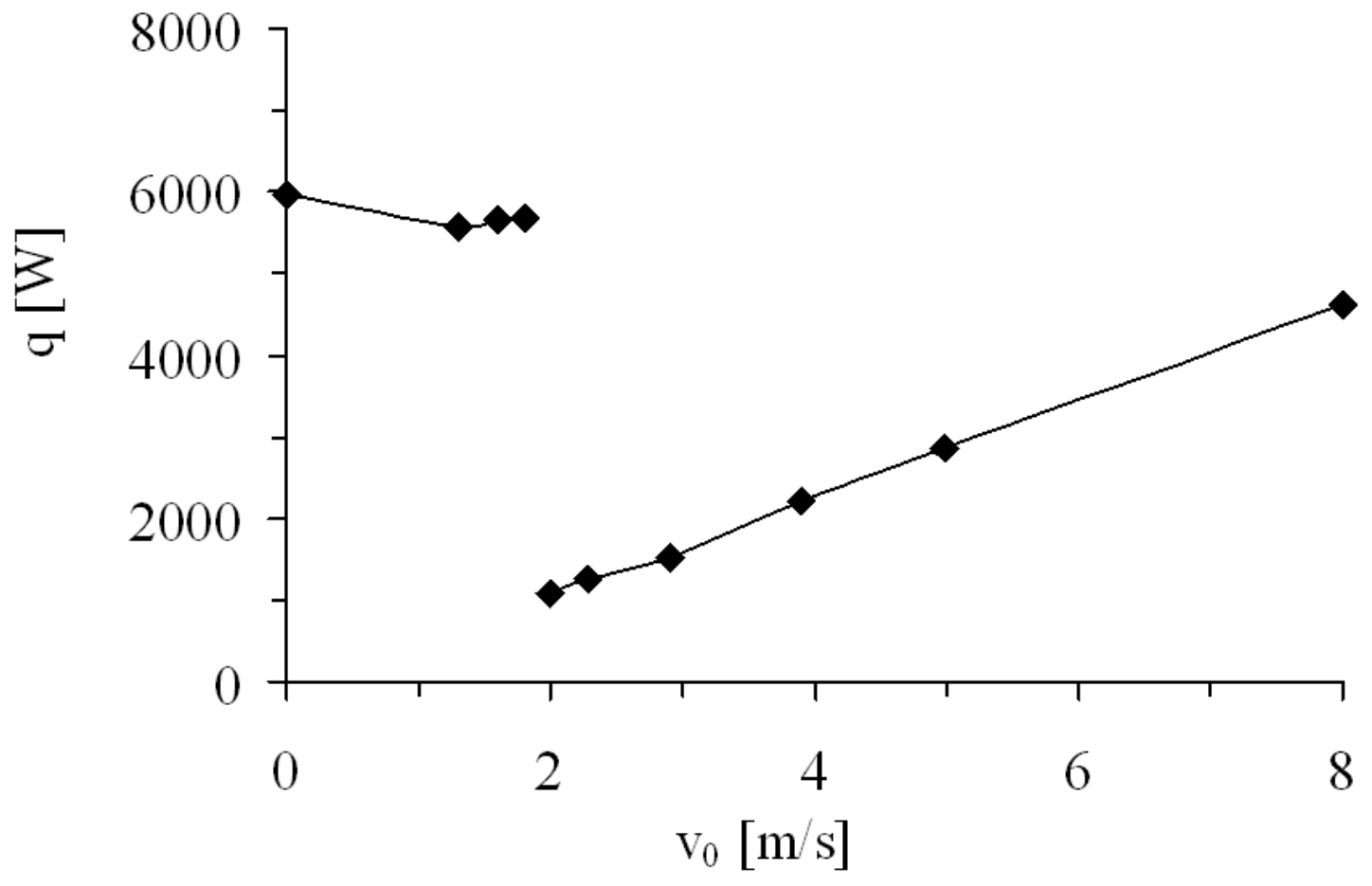


Figure 12

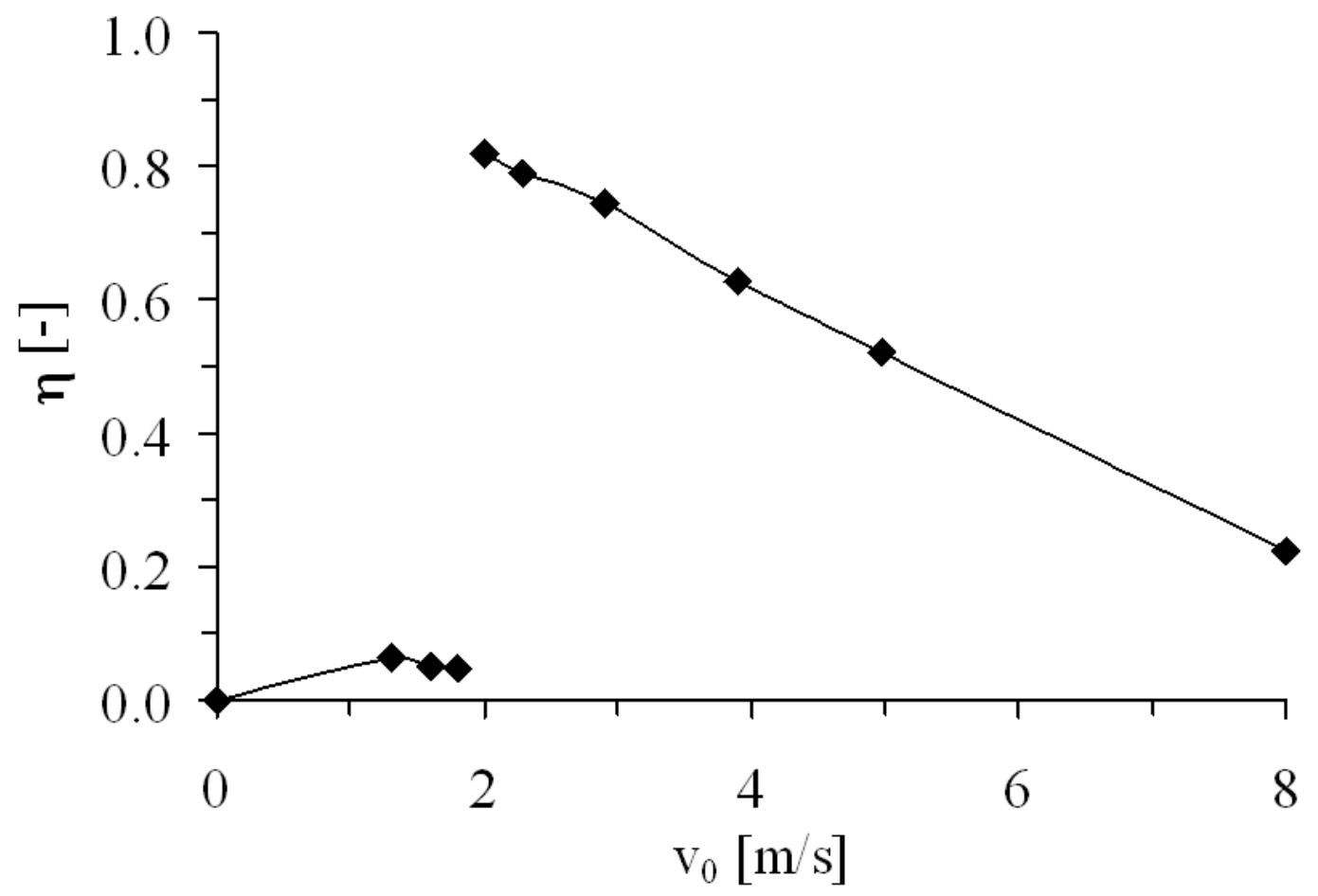


Figure 13

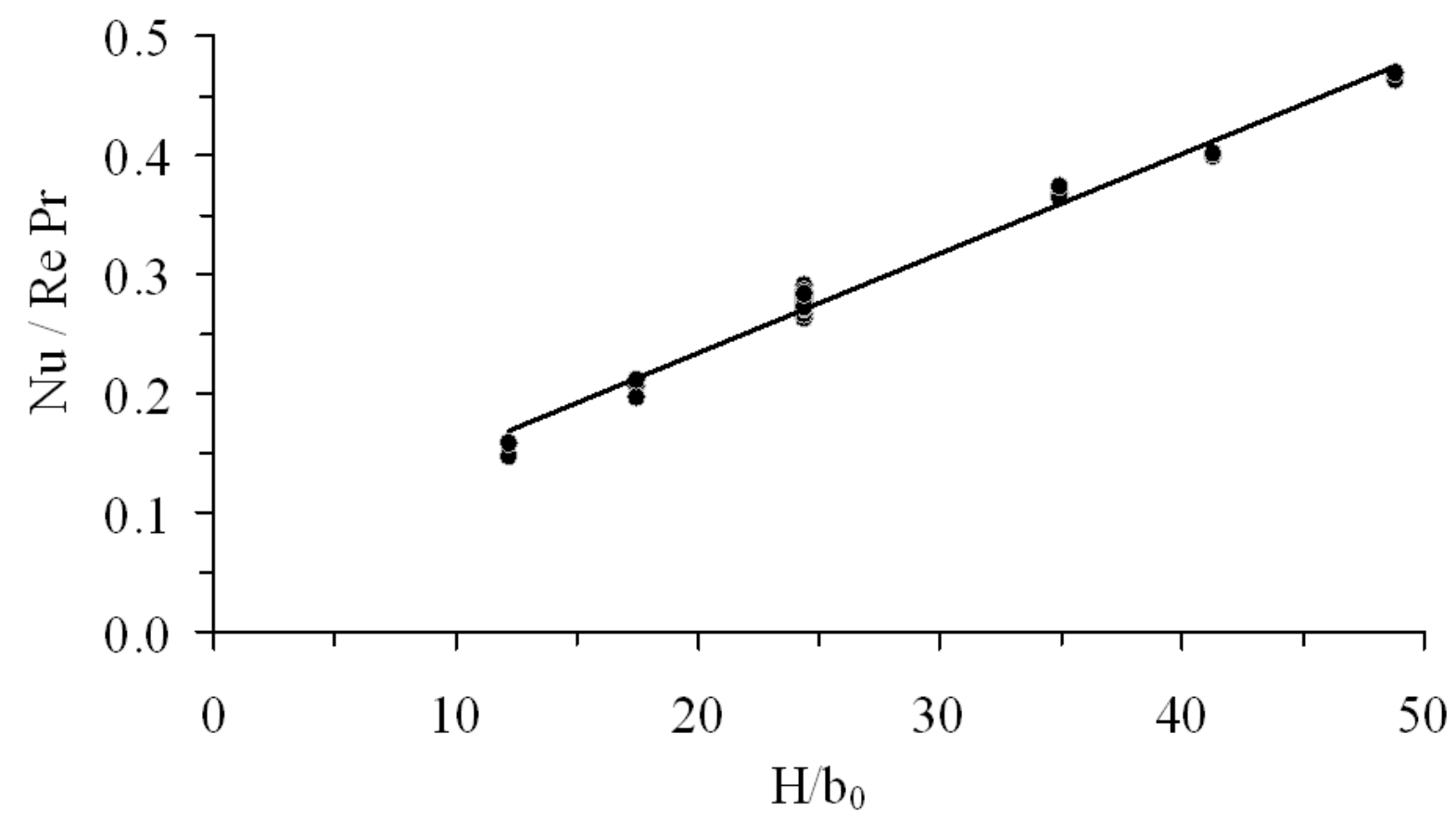



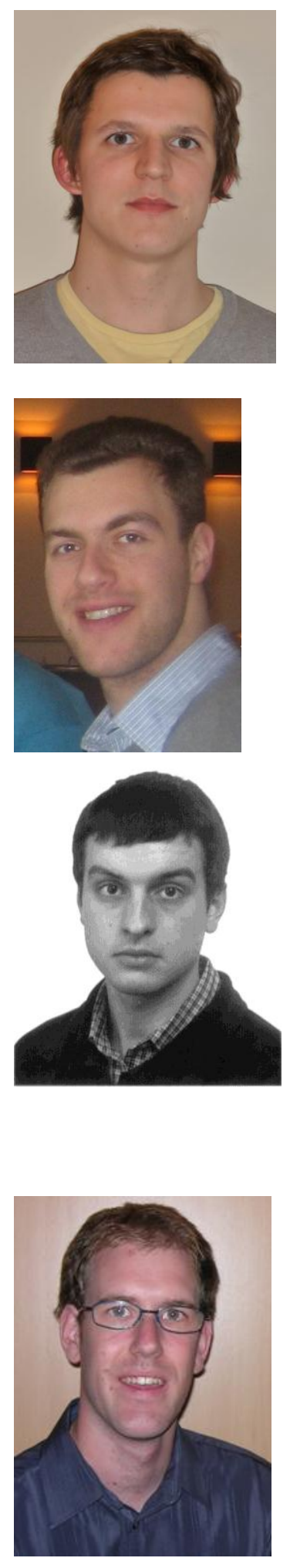

Marnix Van Belleghem ( $\left.{ }^{\circ} 1984\right)$ is a $\mathrm{Ph} . \mathrm{D}$. student at the Research Group Applied Thermodynamics and Heat Transfer in the Department of Flow, Heat and Combustion Mechanics at Ghent University, Belgium. He graduated as M.Sc. in ElectroMechanical Engineering in 2007. Currently, his research is focussed on heat, air and moisture transport modelling in buildings.

Gregory Verhaeghe $\left({ }^{\circ} 1986\right)$ graduated in 2009 as M.Sc. in Electro-Mechanical Engineering at the Ghent University, Belgium, specializing in Mechanical Energy. As master thesis, he conducted a study on air curtains used to restrict infiltration into refrigerated rooms. He is currently working as a design engineer HVAC systems at De Klerck Engineering in Bruges, Belgium.

T'Joen Christophe is a Postdoctoral Researcher at the Department of Flow, Heat and Combustion Mechanics, Ghent University-Ugent, Belgium. He received his Master's degree in Electromechanical Engineering from the Ghent University in 2004 and his Ph.D. in 2008. Currently his main research topic is interrupted fin designs for compact heat exchangers. For his Master's dissertation he was honored with the 'Marcel Herman' price.

Henk Huisseune is a Ph.D. student at the Department of Flow, Heat and Combustion Mechanics, Ghent University, Belgium. He received his Master's degree from Ghent University in 2007. For his master's dissertation, he was honored with the "Umicore Award". Currently, he is doing research on compact heat exchangers, focused on tube-fin junction effects and vortex generators. 

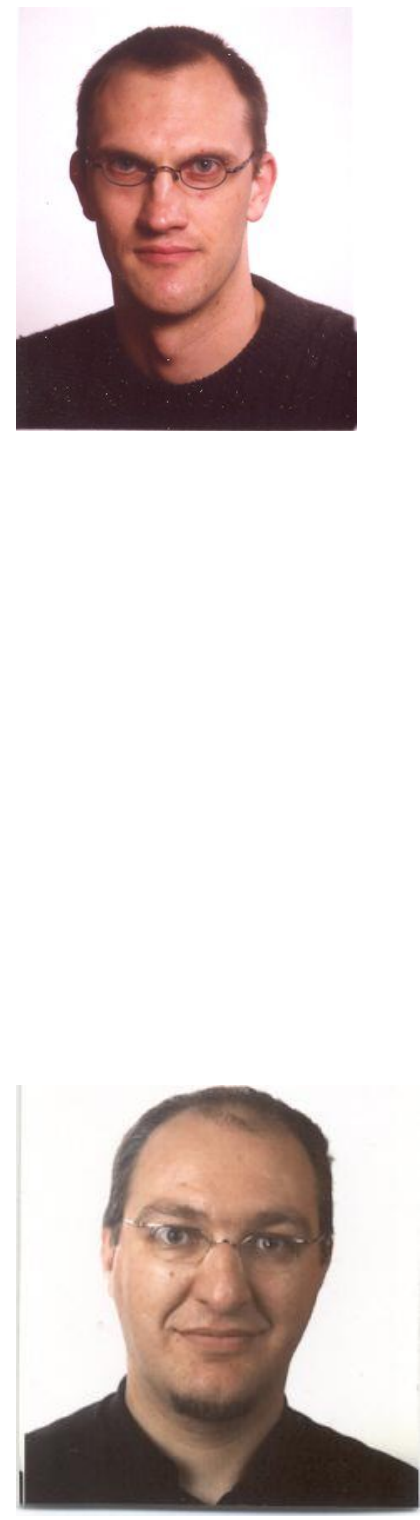

Michel De Paepe $\left({ }^{\circ} 1972\right)$ is professor of Thermodynamics in the Faculty of Engineering at Ghent University. He graduated as Master of Science in Electro-Mechanical Engineering at the Gent University in 1995. In 1999 he obtained the PhD in ElectroMechanical Engineering at the Gent University, graduating on 'Steam Injected Gas Turbines with water Recovery'. In 2005 he spend 3 months as a visiting professor at the University of Pretoria (South Africa), doing research on flow regime detection. He is currently heading the Research Group Applied Thermodynamics and Heat Transfer at the Faculty of Engineering at the Ghent University. Research focuses on: thermodynamics of new energy systems, performance of HVAC systems and energy in buildings and complex heat transfer phenomena in industrial applications, as in compact heat exchangers, refrigerant two-phase flow and electronics cooling. Michel De Paepe is (co)author of 40 papers published in international peer reviewed journals and more than 
150 conference papers. For his master thesis and his $\mathrm{PhD}$ he received the WEL price Energy. 